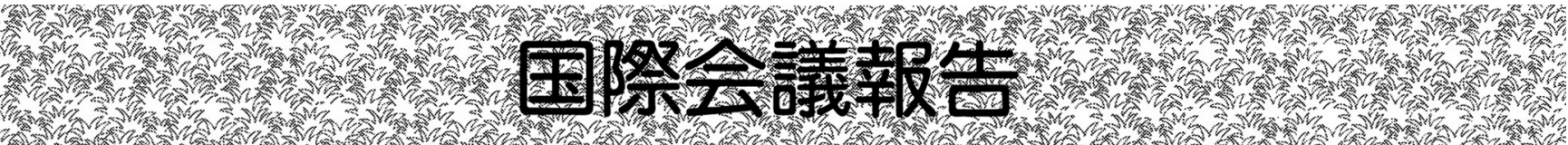

\title{
APCOT2018 \\ 9th Asia-Pacific Conference on Transducers and Micro/Nano Technologies
}

正員 長谷川 義大（広島市立大学）

\section{1. はじめに}

APCOT2018 国際会議は，6月 24 日から 27 日までの 4 日 間の日程で香港にて開催された。本会議は 2002 年から隔年 で，Transducers の開催されない年にアジア・太平洋地区 の各都市で開催されており, 今回が 9 回目となる。会場と なった香港科技大学（HKUST）は，1991 年に設立された 比較的新しい大学で，市内中心部からは地下鉄とバスを乗 り継いで 1 時間ほどのところにある。外海に面した風光明 媚な抜群のロケーションにある綺麗なキャンパスで会議は 開催された。ただ，会期中の香港は降雨こそなかったもの の，高温多湿の環境で会場では極寒であったため，筆者に とっては体調管理が難しかった。

\section{2. 会議概要}

本会議には，21 か国から 157 件の投稿があり，約 $91 \%$ の 143 件の論文が採択された。採択率は例年通りであるが，前 回の APCOT2016（金沢）と比べると投稿数が 40 件ほど減 少したようである。発表の内訳は，口頭発表が 87 件，ポス ター発表が 56 件で, その他に各日 2 件ずつ計 6 件の基調講 演と，10 件のキーノート講演が設けられた。国別の採択件 数は，中国が 45 件と最も多く，次いで日本が 42 件，韓国 13 件，台湾および香港が 5 件ずつとなっている。

初日の基調講演では, MIT の Nicholas X. Fang 教授から 光学，音響分野などを対象とした機能的メタマテリアルの 応用デバイスと製造技術について， ESIEE Paris の Tarik Bourounia 教授からは, Suitable Environment, Smart City の実現に向けた MEMS デバイスについての講演があった。 2 日目は，HKUST の Zexiang Li 教授からドローン開発と HKUST での取り組み, MEMS 技術のドローンへの展開につ いて講演があった。商用ドローン最大手の DJI は Zexiang Li 教授の教え子であった Frank Wang 氏が始めた企業である。 もう 1 件は，台湾の ASE Group の Vice President である C. P. Hung 氏からで，System in Packaging (SIP) 技術の概説 と今後の展望について講演があった。3 日目は, Shanghai Institute of Microsystem and Information Technology Xinxin Li 教授から, Sensing Nanomaterials とその応用例 について, University of Oldenburg の Sergej Fatikow 教授 から, AMiR で開発している産業用マイクロロボットやナノ スケールでの自動化技術について講演があった。

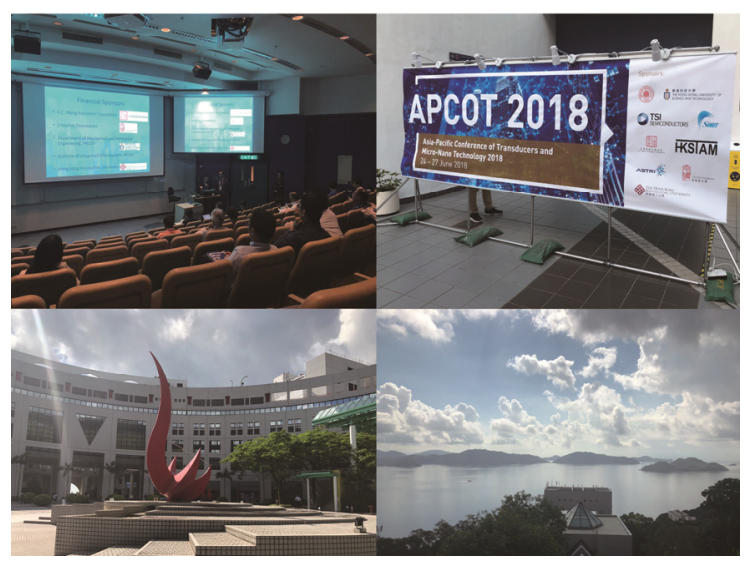

図 1 会議の様子と会場の香港科技大学

表 1 各トピックの講演数

\begin{tabular}{|c|c|c|}
\hline \multicolumn{2}{|c|}{ トピック名 } & 講演数 \\
\hline A & Theory, Design, Analysis, and Simulation & 9 \\
\hline B & Material, Fabrication, and Packaging & 17 \\
\hline C & Physical Sensors, Micro/Nano Fluidics & 21 \\
\hline D & Biological, Medical, Chemical Sensors & 19 \\
\hline E & Actuators, Force Sensors, Power MEMS & 7 \\
\hline F & RF MEMS/NEMS, Internet of Things (loTs) & 2 \\
\hline G & Optical MEMS and Nano-Photonics & 4 \\
\hline
\end{tabular}

一般講演では，表 1 に示す七つのトピックに沿った口頭 発表セッションが 3 会場のパラレルセッション形式で行わ れた。それぞれのトピック名の後ろの数字は各トピックで の講演数である。Physical Sensors, Micro/Nano Fluidics 関連が最も多く, 次いで Biological, Medical, Chemical Sensors のバイオ関連技術, Material, Fabrication, and Packaging の順であり，本会議でも講演数の傾向は近年の 開発傾向と一致しているといえる。

\section{3. おわりに}

次回の APCOT2020 は, 2020 年 5 月 27 日〜29 日に中国 の上海にて開催される予定である。MEMS2016 での記憶に 新しい活気にあふれた上海での開催を, 積極的な投稿でぜ ひ盛り上げていただきたい。投稿締切は 2020 年 1 月 12 日 で，開催時期，投稿締切ともに例年より早いため注意され たい。

(平成 30 年 8 月 6 日受付) 